\title{
Evaluation of Artificial Recharge on Groundwater Using MODFLOW Model (Case Study: Gotvand Plain-Iran)
}

\author{
Manouchehr Chitsazan, Ali Movahedian* \\ Faculty of Earth Sciences, Shahid Chamran University, Ahvaz, Iran \\ Email: chitsazan.mc@gmail.com, “Ali_movahedian@yahoo.com
}

Received 4 June 2015; accepted 25 July 2015; published 28 July 2015

Copyright (C) 2015 by authors and Scientific Research Publishing Inc.

This work is licensed under the Creative Commons Attribution International License (CC BY). http://creativecommons.org/licenses/by/4.0/

(c) (i) Open Access

\begin{abstract}
The managed recharge of groundwater is a stable and newfound technique which has already produced successful results and is expected to solve many of the problems of water resources, particularly in arid and semiarid areas. The aquifer artificial recharge is considered as a strategy for the improvement and development of groundwater resources and their storage to compensate for the damage to them. In this regard, the advanced models of groundwater offer suitable tools for the management and assessment of aquifers. The main objective of this research is Simulation of Gotvand Plain aquifer using MODFLOW code of GMS software is the primary objective of this research. The other objective is assessing the artificial recharge project of Abbid-Sarbishe located in north of Gotvand. For this purpose, the study area was discretized in GMS software and the initial and boundary conditions were specified. Then, the model was calibrated from September 2009 to August 2010 in an unsteady state during 12 stress periods. After the optimization of hydrogeologic parameters, the model was validated from September 2009 to August 2010 and then it was used to assess the artificial recharge. By analyzing the water budget model, the behavior of piezometers and the observed data, the hydraulic of groundwater was evaluated. The results indicate that artificial recharge has been effective in the western parts of the project and the most effective recharge has occurred during 2005-2006 and 2006-2007 around the piezometer G19. This project has a positive effect on the aquifer, but due to seasonal water-flood spreading, sedimentation, and drought in the past years, its effect is not sufficient.
\end{abstract}

\section{Keywords}

Artificial Recharge Evaluation, Modeling, MODFLOW, Groundwater, GMS

\footnotetext{
${ }^{*}$ Corresponding author.
}

How to cite this paper: Chitsazan, M. and Movahedian, A. (2015) Evaluation of Artificial Recharge on Groundwater Using MODFLOW Model (Case Study: Gotvand Plain-Iran). Journal of Geoscience and Environment Protection, 3, $122-132$. 


\section{Introduction}

Groundwater is one of the most important sources of the needed fresh water for human beings that form the largest supply of the Earth's fresh water after the glaciers and ice caps. Unfortunately, the groundwater resources have not been managed scientifically. As a result, decrease of groundwater level throughout Iran due to much extraction of water and digging wells without license is a hurdle that the public agrees on. Only 35 billion $\mathrm{m}^{3}$ out of 400 billion $\mathrm{m}^{3}$ of the average annual rainfall in Iran is recharged to the aquifers and the rest becomes unavailable as runoff [1] [2]. Therefore, floodwater management in semiarid areas seems logical in order to solve the water crisis. In this regard, the artificial recharge of aquifers via floodwater is considered as a strategy to improve and develop groundwater resources and to compensate for their losses in order for storing and updating current flows [3]. Accordingly, detailed study and prediction of the effects of these initiatives as well as their performance evaluation and monitoring seem to be necessary after their establishment.

Artificial recharge has been in use for many centuries for water management. Some of the earliest examples of recharge projects are structures constructed in wadis in historic Persia (Iran, Iraq, Syria, and Jordan) dated to at least $330 \mathrm{AD}$. These structures slowed surface water flowing in the wadis to increase infiltration and recharge aquifers supplying qanats [4].

The European Environment Agency [5], shows an increasing trend in artificial recharge in a number of countries such as Belgium, Denmark, Finland, Greece, the Netherlands, Poland, Spain and Switzerland. Other countries in which artificial recharge methods are in use include Australia, Austria, Hungary, Iran, Israel, Jamaica, Morocco, and South Africa.

Mathematical groundwater models are used to simulate aquifer conditions, to estimate aquifer parameters, and to predict groundwater condition. In addition, as groundwater is essentially a hidden resource, studies on groundwater under both natural and artificial boundary conditions require modeling techniques.

As groundwater is fundamentally a concealed resource and there are many breaks in the accessible data; consequently studies of groundwater under both natural and artificial conditions have used modeling techniques. Groundwater models express groundwater flow using mathematical equations that are based on definite simplifying assumptions. As a result, groundwater modeling has become a very important process in managing groundwater resources [6].

The use of numerical models for modeling groundwater flow has been emphasized in many research studies during the past decade [7]. Several studies have been achieved worldwide that used the variety of the MODFLOW model for aquifer management. These kinds of software are linked to GIS technology and provide an appropriate graphical interface for the users and play an important role in the evaluation and management of groundwater in many countries [8]. For example, the following studies can be referred to:

Parsiopoolos (1995) evaluated the recharge of Vadi Tabalah aquifer in the southwestern part of Saudi Arabia due to sudden flood waters via simulation. The recharge of the aquifer was examined utilizing a two-dimensional saturated-unsaturated numerical model for a sudden floodwater [9].

In order to investigate the effect of land use on the discharge and recharge of groundwater in East China, Paul (2006) combined MODFLOW and WETPASS models with each other. The results of the research indicated that the main reason for recharge reduction in the studied area was urban development and agricultural lands in general. However, the lands with forests can be effective in maintaining and preserving aquifer and its dependent ecosystems [10].

Chenini and Ben Mamou (2010) made use of GIS and numerical modeling in order to specify the proper location of artificial discharge and development of groundwater resources. MODFLOW code was used to estimate the effects of recharge on the piezometric behavior of hydrogeologic system and to manage groundwater resources in the studied area, as well [11].

In a case study, Danaeian (1997) evaluated groundwater with an emphasis on artificial and natural recharge. In this research, which was carried out on Ibrahim Abad Plain in Yazd, MODFLOW model was used for the simulation of groundwater and the effects of artificial recharge on groundwater reservoirs [12].

Ashtiani Moghadam et al. (2003) provided the artificial recharge model of NAZ Plain in Sarry in order to prevent the development of saltwater using MODFLOW software. Using this model, they showed that the southwest regions near the Neka River and a region in the southeastern part of the Tajan River were the most suitable areas for the recharge of Naz Plain [13].

Katibeh and Hafezi (2004) investigated the groundwater utilization management and evaluated the perfor- 
mance of artificial recharge of Ab Barik Plain in Bam using the MODFLOW model. First, they simulated the aquifer using the available data and then they used the constructed model for different managerial scenarios and also for the evaluation of artificial recharge performance [14].

Rezaei and Sargezi (2009) studied the effects of artificial recharge on the aquifer of Goharkooh Plain and specified the best location for the implementation of artificial recharge using MODFLOW model. The results showed that the aquifer response to artificial recharge was positive and the artificial recharge didn't have a destructive effect on the aquifer [15].

Nozarpoor (2014) evaluated Jarmeh floodwater spreading using MODFLOW model and quantitative and qualitative data of the aquifer. The results indicated that artificial recharge had a positive effect on the aquifer water budget, but it had no effect on its quality [16].

The main objective of the present work is to evaluate the Abbid-Sarbishe Floodwater Spreading in Gotvand plain in southwest of Iran using MODFLOW mathematical model. After proving conformity with the natural condition of the aquifer, the effects of artificial recharge to groundwater level was determined by water budget and analyzing water level behavior of piezometers in the study area.

\section{Study Area}

The studied area of Gotvand Plain is located in the Karun catchment area in north of Khuzestan Province in Iran, between the longitudes $48^{\circ} 3^{\prime}$ to $49^{\circ} 1^{\prime}$ and the latitudes $32^{\circ} 00^{\prime}$ and $32^{\circ} 30^{\prime}$.Gotvand plain is an unconfined aquifer with a single layer. According to the geological divisions, the plain is located at wrinkled Zagros [17], and is surrounded by the conglomerates of Gachsaran, Mishan, Bakhtiari, Aghajari, and Lahbari district. The sequence of stratifications has surrounded terraces, cliffs, and the northern part of the region and the Karun River passes through them and enters Gotvand Plain. The main surface water feature in the watershed is the Karun River that passes through the eastern edge of Gotvand Plain and the western edge of Aghili Plain. The height of the earth's surface is about 50 to 250 meters range and general slope of the region is from north to south. The plain's deposits result from the sedimentation of Karun River and the erosion of the adjacent conglomerate formation (Figure 1). The average annual rainfall during the considered period in the weather station of Gotvand City is $406.7 \mathrm{~mm}$. The highest annual rainfall within the year belongs to December by the average of $97.1 \mathrm{~mm}$ and the lowest rainfall belongs to June, July, and August by the average of $0 \mathrm{~mm}$. The area has a semiarid climate [18].

Abbid-Sarbishe floodwater spreading plan covers an area of 440 hectares in the alluvial fan of the northern heights of Gotvand Plain. The plan doesn't contain constant surface flows and the main watercourses draining the spreading area join the Karun River in its south. The floodwater spreading area is located in a Syncline

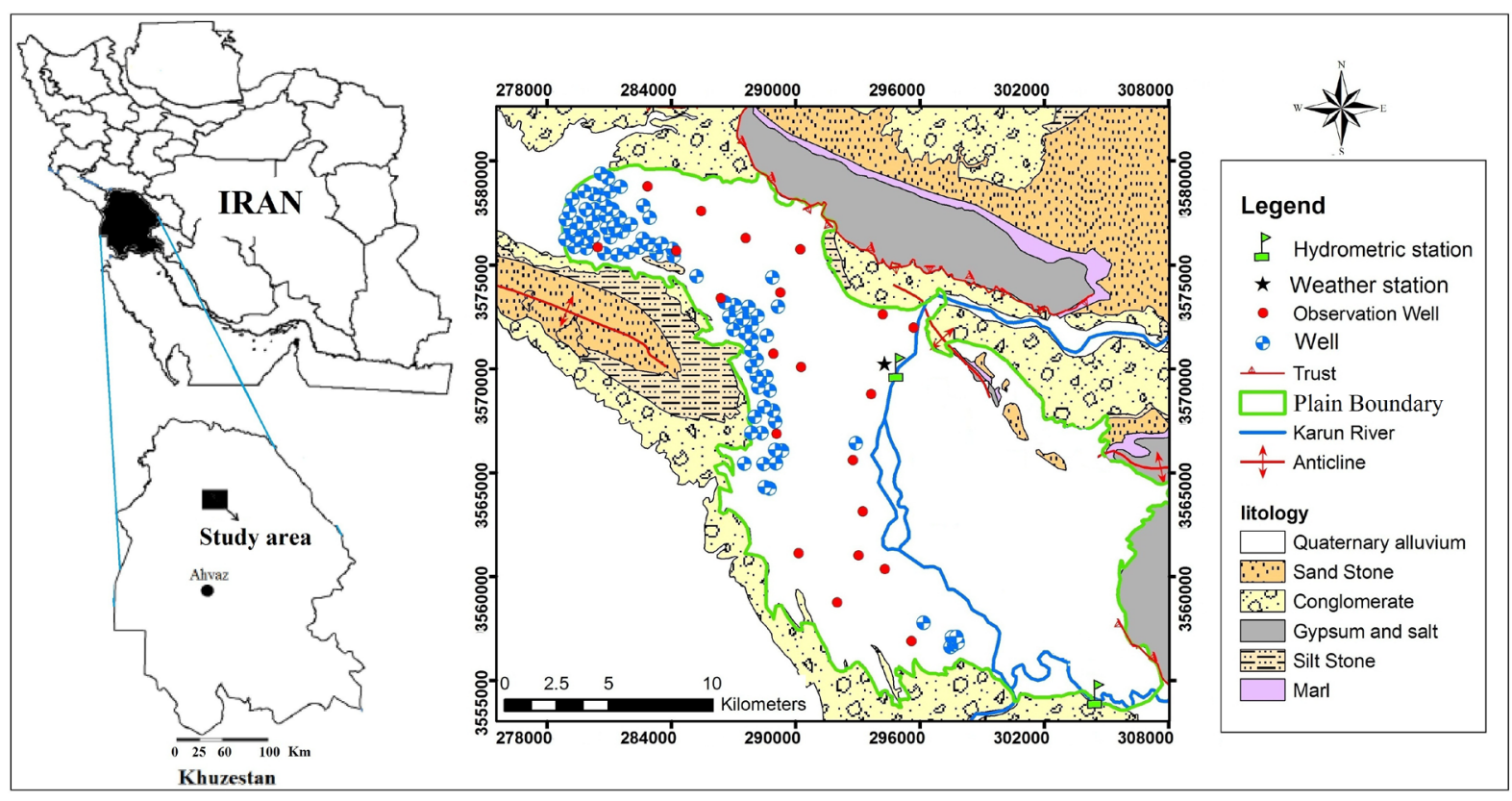

Figure 1. The geographical location and geological condition of the study area. 
which is often filled with alluvial deposits resulting from Aghajari and Bakhtiari conglomerates. Bakhtiari conglomerate which is an alternation of hard conglomerate and conglomeratic sandstone is widely seen in the area and is the origin of coarse sediments in the area. Studies show that the alluvial deposits in the study area contain an alternation of fine-grained layers like clay and coarse-grained layers like gravel with different thicknesses.

The project was implemented in 1996 by the Ministry of Agricultural Jihad in order to manage aquifer and watershed plans and to recharge groundwater resources. Since the launch of the project up to now, a considerable volume of floodwaters has been recharged to aquifer. The volume of floods and water-flood spreading has been approximately calculated based on the flood flow, level of flood mark, and also the spreading area (Table 1) [19].

\section{Materials and Methods}

In order to evaluate artificial recharge through the numerical model, first of all a conceptual model using hydrologic and hydrogeologic data, such as hydraulic conductivity, water level in observed wells, rate of recharge resulting from rainfall and returned water of agricultural wells, wells discharge, boundary conditions, distribution of geological formations, surface topography of land and the aquifer bottom elevation was generated. The MODFLOW 2000 code in GMS software was used for modeling the groundwater flow in the study area.

After preparing the conceptual model, the study area was discretized into 42 columns and 52 rows of central block with the width and length of $500 \mathrm{~m}$ (Figure 2). According to the maps of flow direction and hydrogeologic views of the plain, the main input boundaries are located in the north, northwest, and west of the plain. The main output boundaries are located in eastern (Karun River) and the south parts of the plain. In order to apply the Karun River in the model, River package and the data from Gotvand hydrometric stations were used.

According to the plain unit hydrograph and based on the aquifer data, the model was calibrated at steady state and the aquifer hydraulic conductivity was obtained. Then, according to purpose of this article 'evaluation of artificial recharge' because of drought and lack water ponding in recent years, aquifer model was prepared for the years 2008-2009. The model was calibrated for the specific yield of the aquifer at an unsteady state from September 2008 to August 2009 for 365 days in 12 stress periods for obtaining specific yield of the aquifer. The aquifer hydraulic parameters were calibrated via PEST code in GMS software. The model was validated for a 12-month stress period from September 2009 to August 2010.

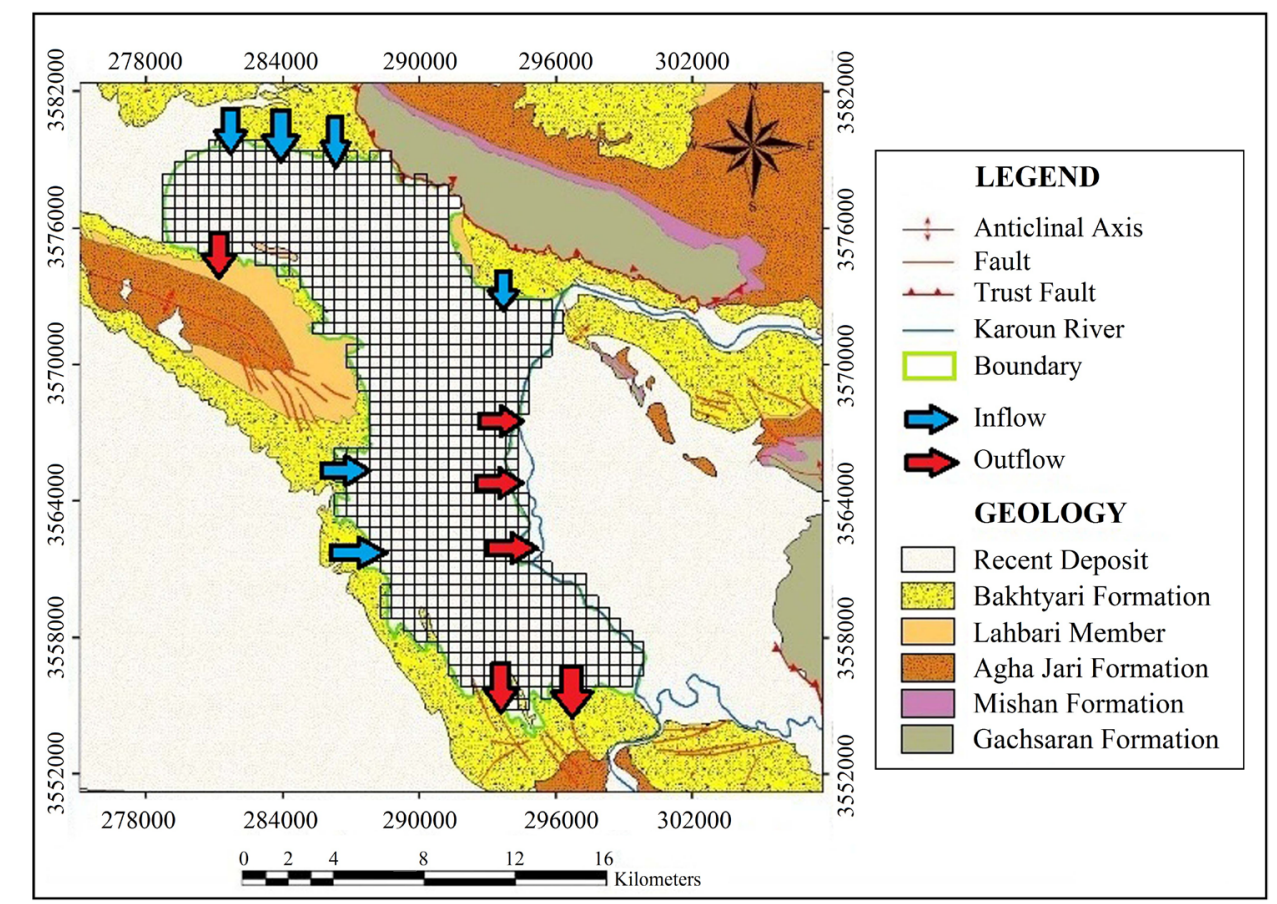

Figure 2. Conceptual model of Gotvand-Aghili Plain groundwater along with networking and boundary condition). 
Table 1. Water-flood spreading date and the estimated volume of recharge.

\begin{tabular}{cccc}
\hline $\begin{array}{c}\text { Volume of recharged } \\
\text { water (mcm) }\end{array}$ & Floodwater spreads date & $\begin{array}{c}\text { Volume of recharged } \\
\text { water }(\mathrm{mcm})\end{array}$ & Floodwater spreads date \\
\hline 0.214 & $2006 / 3$ & 0.235 & $2003 / 3$ \\
0.463 & $2007 / 1$ & 0.658 & $2003 / 11$ \\
1.026 & $2007 / 3$ & 0.695 & $2003 / 12$ \\
0.15 & $2009 / 10$ & 3.712 & $2004 / 1$ \\
0.4 & $2009 / 12$ & 0.575 & $2004 / 12$ \\
0.056 & $2011 / 1$ & 0.463 & $2005 / 12$ \\
0.093 & $2011 / 11$ & 0.621 & $2006 / 1$ \\
0.048 & $2012 / 2$ & 1.74 & $2006 / 2$ \\
\hline
\end{tabular}

After the construction of Gotvand Plain aquifer model, it was used as a management tool to investigate and evaluate the quantitative effects of Abbid-Sarbishe artificial recharge on the aquifer. In this regard, the fluctuations of water level in piezometers surrounding the project were predicted by the model. Then, calculated water levels were compared with the observed water level and were interpreted.

\section{Results and Discussion}

Following the processes of designing and calibrating the model and then verifying the consistency of mathematical model with natural conditions of the aquifer, the model can be used for the aquifer management. In this study, the constructed model was used to evaluate the effect of artificial recharge of Abbid-Sarbishe on the water level of the aquifer. Therefore, designing an accurate model and its calibration was the essential step to achieve the goals of the study. Using the model, the effect of artificial recharge will be investigated from different viewpoints.

\subsection{The Project Effective Domain According to Piezometric Fluctuation}

The model is an appropriate tool to investigate and observe the effect of the project on the aquifer and the piezometers of the region. Thus, the prepared model in the water year of 2008-2009 was run in two approaches, namely approach A (with artificial recharge) and approach B (without artificial recharge).

Approach A: This approach belongs to dry year of 2008-2009. No artificial recharge was implemented in the plan during this year because of drought.

Approach B: This approach is considered for implementation of artificial recharge of the project and further, is divided to sub-case approach of R1, R2, R3, R4, R5, and R6 according to hypothetical recharge of 0.00001 , $0.0001,0.001,0.0005,0.001,0.005$ and $0.01 \mathrm{~mm}$ respectively.

The results of various approaches were compared and their effects on the water level of piezometers and the time effect of water spreads were calculated. The outcomes indicate that as the length from the project site increases, effect of artificial recharge decreases naturally and the time of influence on the water level in the desired point increases.

To look into the effect of recharging floodwater at north of Gotvand, the piezometers G3, G17, and G19 in the northerly part of Gotvand Plain were selected and their water levels at different recharge conditions were compared. Recharge was applied to the model as the default at the first stress period (September) to specify the time of maximum effect on mentioned piezometers. Figure 3 shows the equipotential lines of water level around the artificial site and the maximum effected (groundwater mounding) area resulting from the maximum hypothetical recharge. By magnifying the affected area of recharge, the figure has shown how the contour lines change as a result of maximum recharge. The results of artificial recharge also indicate that the highest effect of the plan is on piezometer G17, and G19, respectively (Figure 4). Piezometer G17 is at the downstream of the floodwater spreading area and G19 is a little away at upstream.

In order to measure the effect of each recharge approach on the rise of water level, water levels in piezometers under the approach " $\mathrm{A}$ " were subtracted from water levels in piezometers under approach " $\mathrm{B}$ " and the result was 


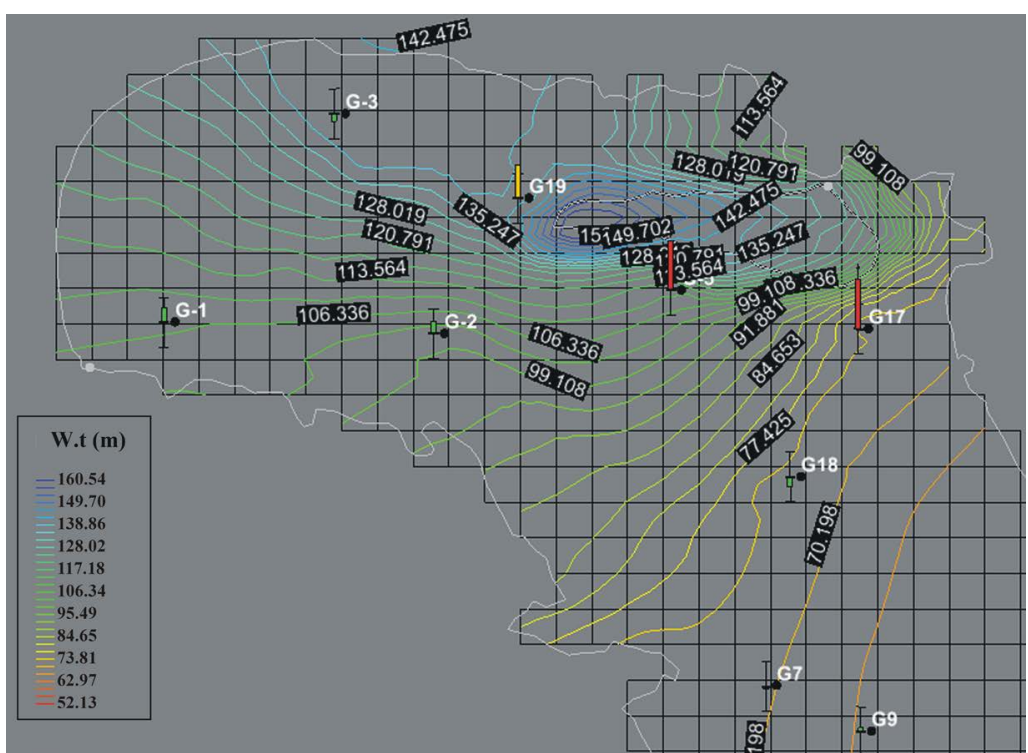

Figure 3. Equipotential lines of water level due to application of maximum recharge $(0.01 \mathrm{~m} /$ day $)$.

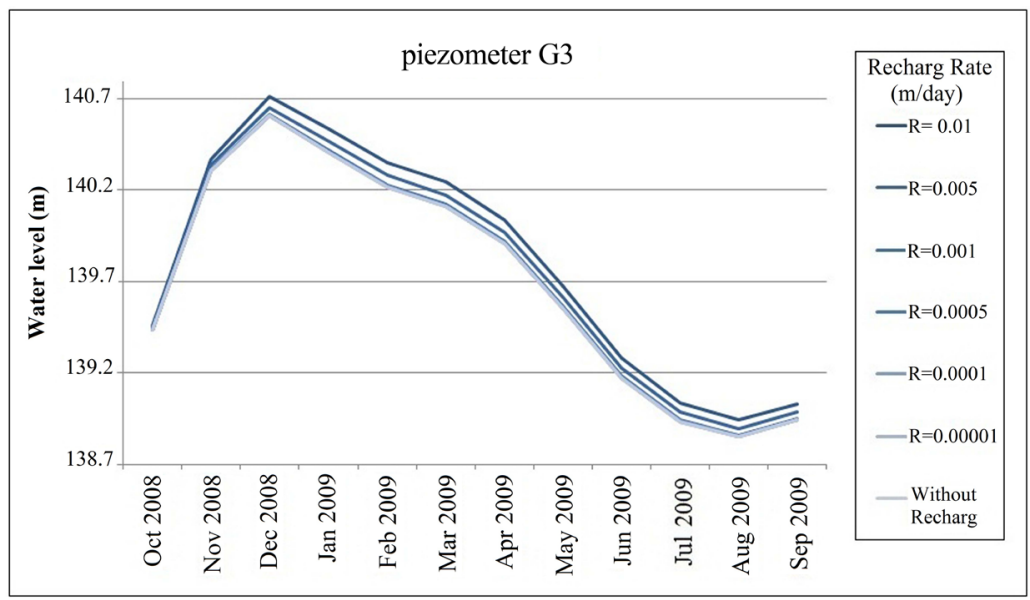

(a)

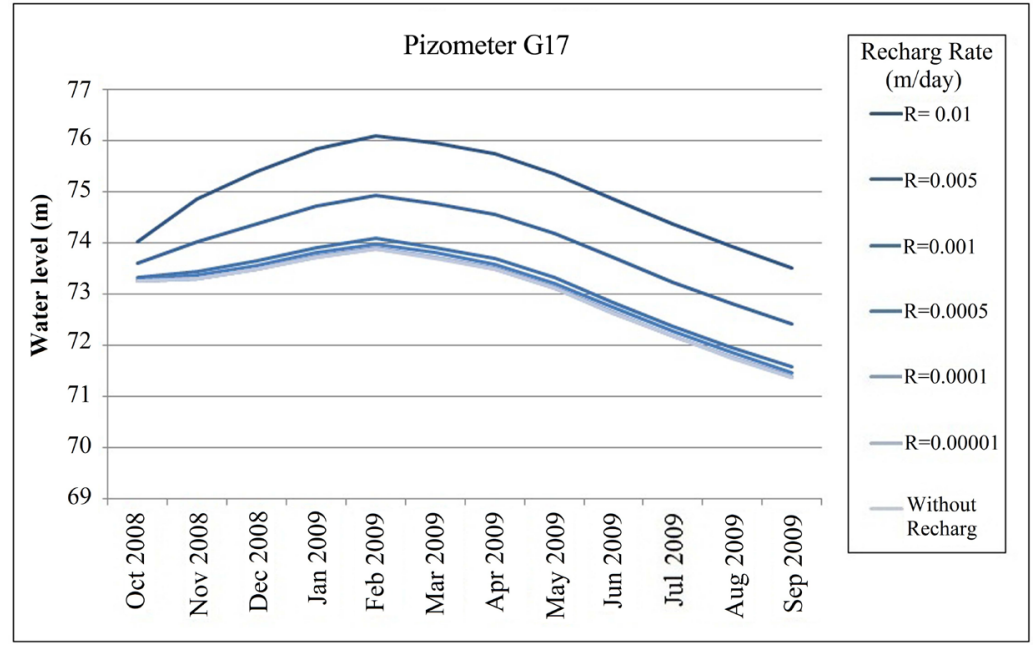

(b) 


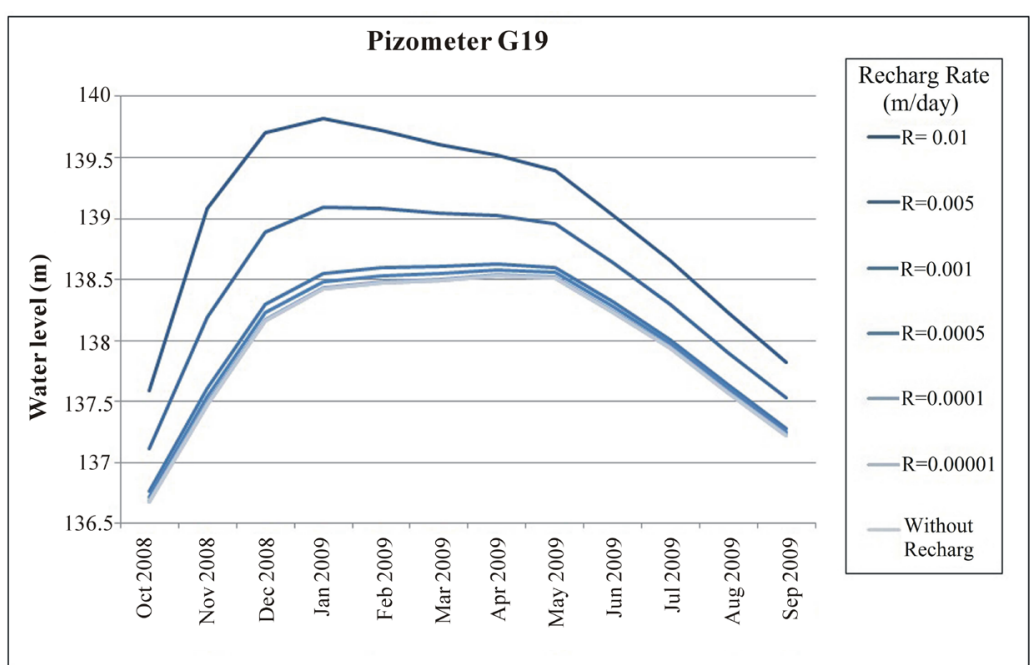

(c)

Figure 4. The effect of different recharge approaches on piezometers around the project area.

calculated for 12 months (the model year).

The rise of water level in piezometer G17 ranges from $2 \mathrm{~mm}$ to $2.25 \mathrm{~m}$. The rise of water level in G19 piezometer which is the closest piezometer to upstream ranges from $1 \mathrm{~mm}$ to $1.6 \mathrm{~m}$. The maximum rise of water level in this piezometer is observed in 60 to 90 days after water-flood spreading. The calculated time period of the rise of water level, is clearly observed during 2005-2006 and 2006-2007, after the water-flood spreading of the artificial site (Figure 5). As this figure shows, the piezometer G19 has unusual peaks during these two years, that are different from the peaks of the other piezometers. The results of the model and artificial recharge, somewhat interpreted by the behavior of this piezometer.

Although, piezometer G19 is located at upstream of the artificial recharge site, but due to its proximity and low value of hydraulic conductivity in sections below it, has been affected by artificial recharge project Even though piezometer G3 is at the upstream of artificial site, due to the groundwater mounding created by the artificial recharge, a hydraulic barrier has been made in the path of groundwater flow. Thus, the water budget has been changed and ultimately water level in piezometer G3 has increased. The water level in piezometer G3, at the maximum recharge rate $(0.01 \mathrm{~m} /$ day $)$, reaches to the maximum of $13 \mathrm{~cm}$. This increase occurs 120 to 150 days after the water-flood spreading that is consistent with the observed data of this piezometer (Figure 6).

The results of the model indicate that the western parts of the site have more influence on the aquifer recharge than the other parts. In conducting approaches with various hypothetical recharges, the effects of artificial recharge of groundwater were clearly observed. The results are consistent with the observed data in the area and piezometer G19 has the fastest responses to the artificial recharge.

At the highest applied recharge, some of the cells of the western side of the artificial site became flooded due to the recharge. According to the results, if the recharge volume is too much, there will be a risk of flooded cells and groundwater mounding in the western parts of the aquifer. However, due to the seasonal performance, low volume of water-flooding and the low frequency, the risk of too high water level is unexpected. Because the thickness of the unsaturated zone in the western side of the aquifer is low, artificial recharge is more influential in this part of the aquifer. In addition, this part is close to the Bakhtiari conglomerate which is recharging boundary of the aquifer.

\subsection{Evaluation of Artificial Recharge via the Water Budget}

One of the results of artificial recharge is the change of water budget proportion in different points of the study area. As mentioned before, since the construction time of Abbid-Sarbishe site, floodwater spreading has been occurred several times. According to the data, one of the best water-flood spreading occurred in the water year of 2005-2006 while there was no occurrence of water-flood spreading in 2004-2005 period. When the artificial 


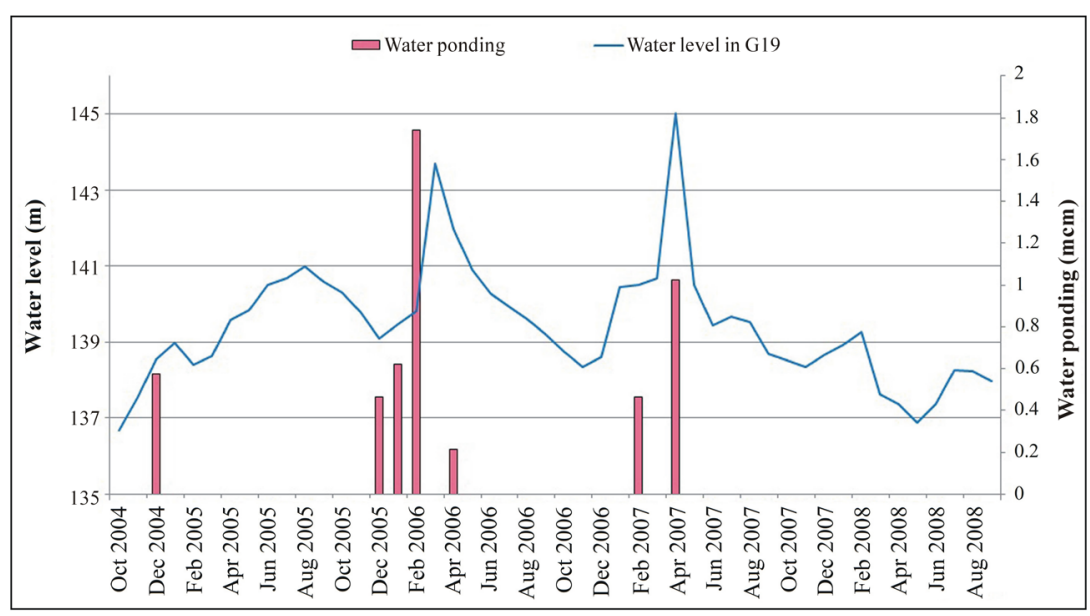

Figure 5. Observation hydrograph of piezometer G19 during water-ponding periods.

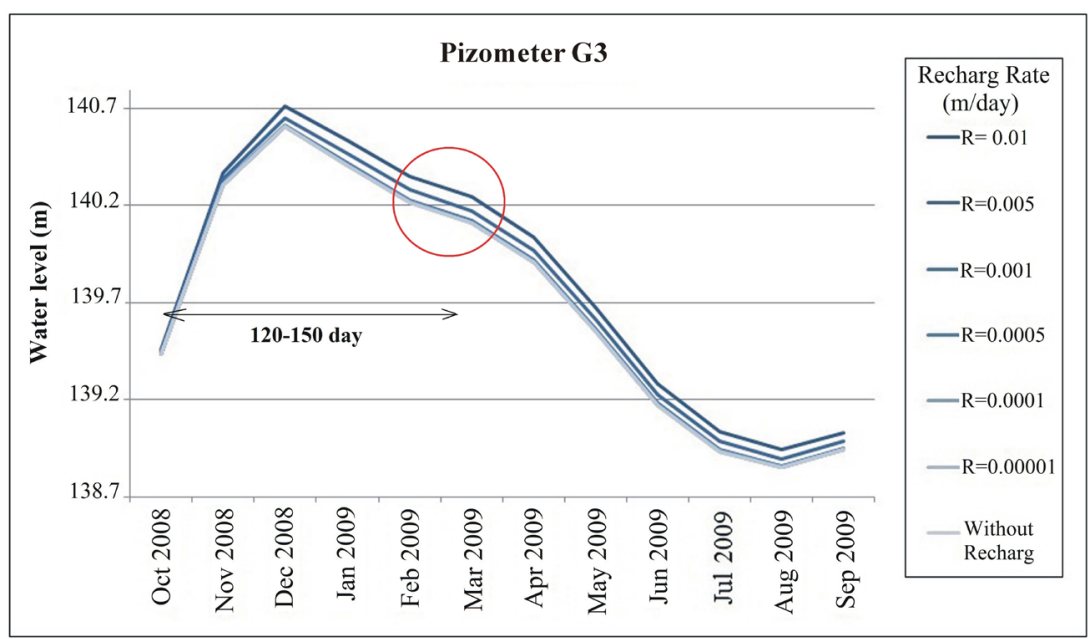

Figure 6. The rise of water level in piezometer G3.

recharge is effective within the site, the water budget has increased along with it. Therefore, to test the artificial recharge function, groundwater model in periods 2004-2005 and 2005-2006 was used. Then the water budget was determined for the study area.

Then, the water budget was determined for tow fixed zones, using the Zone budget package. One zone was the area of Abbid-Sarbishe plan and the piezometers around it and the other zone was the area away from the site which was not much affected by it (Figure 7). To compare the two zones, the water budget ratio for these two zones during the months of water-flood spreading in both years was calculated (Table 2). There was no water-flood spreading in 2004-2005, but in 2005-2006 water-flood spreading was done during November, December, January, and March. If the plan has been effective, the water budget ratio should have changed in the period 2005-2006, when the water has been replenished (Figure 8).

As figure shows, after the water-flood spreading in 2005-2006, the water budget ratio of two zones has changed significantly. In addition, it was trying to calibrate the piezometers around the artificial recharge site for the years 2004 to 2007 accurately. For this purpose, the original framework and hydraulic parameters of the model were not changed. Constructing the model for these years is to some extent considered as the backward validation. During the calibration, the peaks of piezometer G19 that belong to water-flood spreading in these years were simulated just by applying recharge to the cells near the piezometer (Figure 9). The result indicates the multiplier effect of recharge on this piezometer, rather than the other ones. That reflects a hydrogeologic stress in the region which does not affect the other piezometers and the model has failed to predict it. However, it is found via this model that the stress is the result of artificial recharge because there is no well, irrigation 


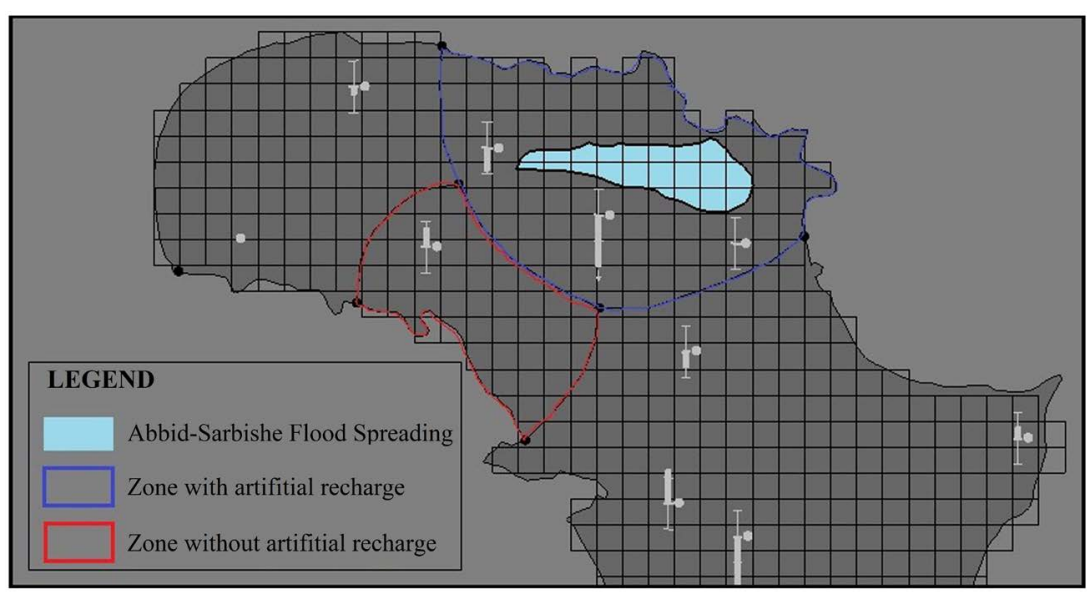

Figure 7. Zones used for calculation of balance ratio.

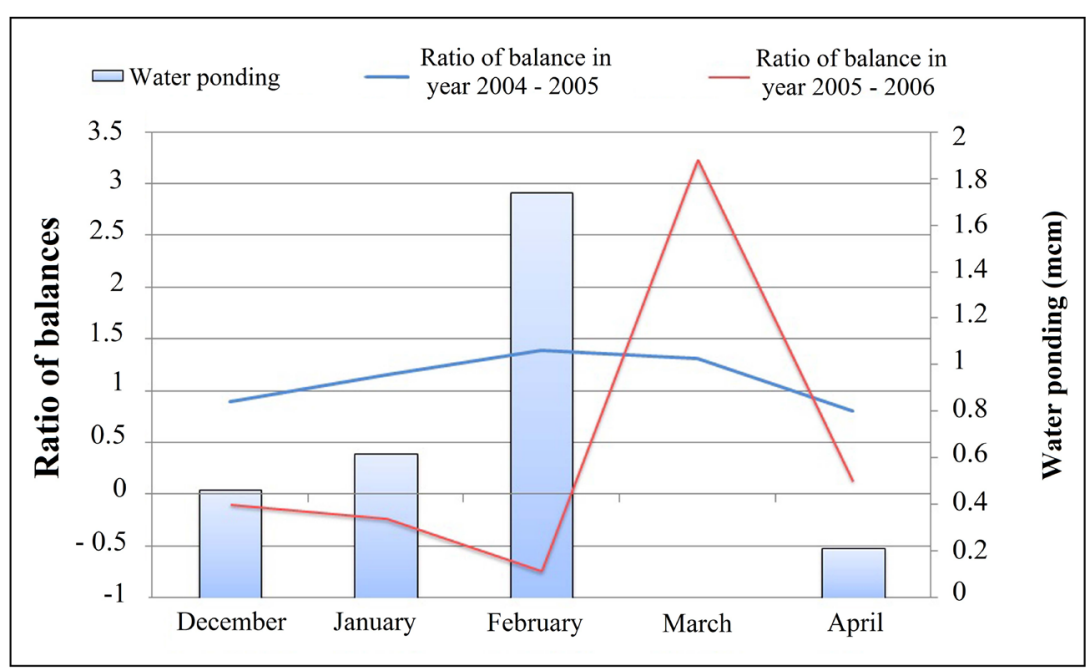

Figure 8. Water budget ratio in two zones for water years of 2004-2005 and 20052006.

Table 2. Water budget ratio in two zones of the influence of artificial recharge.

\begin{tabular}{cccc}
\hline \multicolumn{3}{c}{ Balance ratio both zones } \\
\hline Month & $\begin{array}{c}\text { Year } \\
2004-2005\end{array}$ & $\begin{array}{c}\text { Year } \\
2005-2006\end{array}$ & $\begin{array}{c}\text { Volume of estimated } \\
\text { recharge (MCM) }\end{array}$ \\
\hline December & $2006 / 3$ & 0.235 & $2003 / 3$ \\
January & $2007 / 1$ & 0.658 & $2003 / 11$ \\
February & $2007 / 3$ & 0.695 & $2003 / 12$ \\
March & $2009 / 10$ & 3.712 & $2004 / 1$ \\
April & $2009 / 12$ & 0.575 & $2004 / 12$ \\
\hline
\end{tabular}

network and hydraulic structure in this part of the Plain.The results of the model show that the water level in piezometer G19 has increased 1 to $2 \mathrm{~m}$ after the water-flood spreading plan during 2005 to 2007 (Figure 9).

\section{Conclusions}

Due to the presence of different conglomerates, the aquifer in the study area has heterogeneous character, resulting 


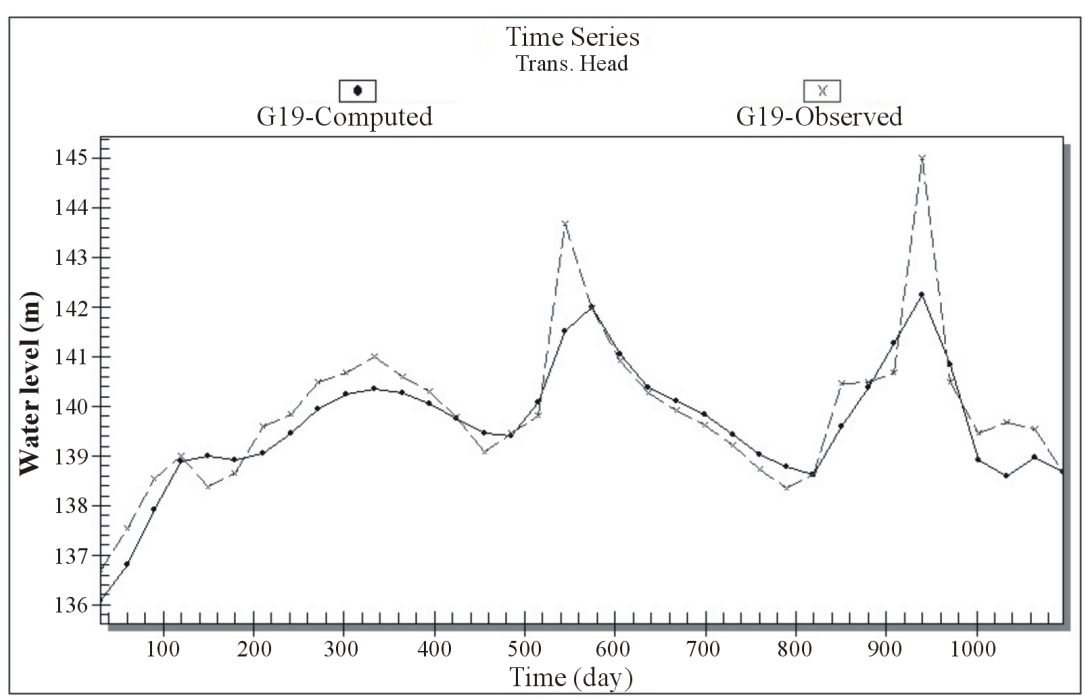

(a)

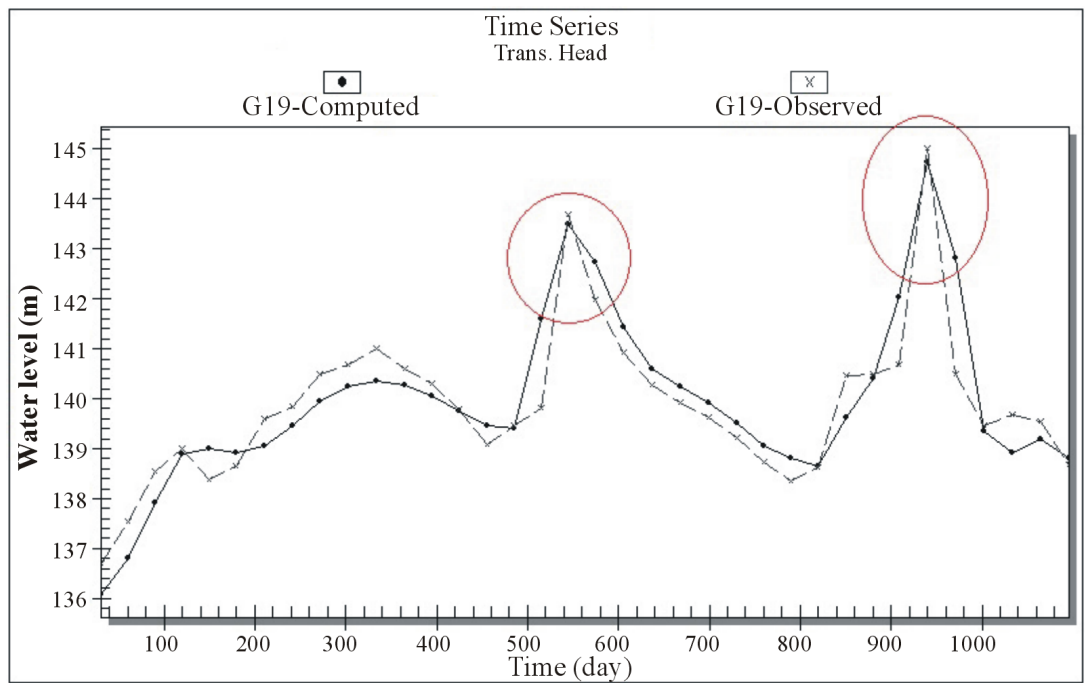

(b)

Figure 9. Calibration of piezometer G19 by artificial recharge. (a) Before calibration; (b) After calibration.

from the erosion of these conglomerates. This heterogeneity is particularly more distinct in the northern areas and within the artificial site. The results of the model show that there is a low hydraulic conductivity zone on the artificial recharge site. The groundwater model in the plain can be used as a tool to evaluate the effects of artificial recharge. According to the model prediction, the highest effect of artificial recharge is on piezometer G5, and then G17 and G19.

It should be noted that piezometer G5 was not working during the desired water-flood spreading periods. The interpretation of model results with the observed data clearly shows the effect of artificial recharge the interpretation of model results with the observed data clearly shows the effect of artificial recharge on piezometer G19. According to this, the water level in this piezometer has increased 1 to 2 meters during 2005 to 2007. The maximum effect of artificial recharge on piezometer G19 is observed 60 to 90 days after water-flood spreading. This time period for piezometer G3 at the upstream area ranges from 120 to 150 days. However, due to particular hydraulic conditions of the region, for a longer period of time up to the next 10 months G5 piezometer will be affected.

Compared to other areas of the plain which have artificial recharge potential, Abbid-Sarbishe floodwater spreading cannot make sufficient use of infiltrated water due to being located at low hydraulic conductivity zone. 
Although the present artificial recharge operation makes the water budget positive, due to low specific yield and being away from consumption area, the project has a low efficiency.

Western parts of Abbid-Sarbishe floodwater spreading had more effect on the aquifer due to less thickness of the unsaturated part of the aquifer. It is observed, although piezometer G19 are located upstream of the site, its effect on aquifer is better than other piezometers surrounding the site. In other areas of the piezometers around the site, the depth of water table level is high and the response to the plan water-flood spreading depends on the greater size and more continuity of artificial recharge operation. Due to the recent droughts, seasonal waterflood spreading, and sedimentation in artificial recharge site, the plan hasn't had a considerable performance in the recent years.

\section{References}

[1] Foltz, R.C. (2002) Iran's Water Crisis: Cultural, Political, and Ethical Dimensions. Journal of Agricultural and Environmental Ethics, 15, 357-380. http://dx.doi.org/10.1023/A:1021268621490

[2] Mohammadnia, M. and Kowsar, A. (2003) Clay Translocation in the Artificial Recharge of a Groundwater System in the Southern Zagros Mountains, Iran. Journal of Mountain Research and Development, 23, 169-185. http://dx.doi.org/10.1659/0276-4741(2003)023[0050:ctitar]2.0.co;2

[3] Kia Heirati, J. (2002) Investigating the Performance of Floodwater Spreading Networks in Moghar Ardestan in the Artificial Recharge of Groundwater Aquifers. Iranian Journal of Natural Resources, 55, 159-171.

[4] CAP (2014). http://www.cap-az.com/index.php/departments/recharge-program/recharge-in-arizona

[5] Lallana, C. and Krinner, W. (2001) Sustainable Water Use in Europe. Part 2: Demand Management. Environmental Issue Report No. 19.

[6] Hashemi, H., Berndtsson, R., Kompani-Zare, M. and Persson, M. (2013) Natural vs. Artificial Groundwater Recharge, Quantification through Inverse Modeling. Hydrology and Earth System Sciences, 17, 637-650. http://dx.doi.org/10.5194/hess-17-637-2013

[7] Mohammadi, K. (2008) Practical Hydroinformatics. Water Science and Technology Library, Springer Verlag, Berlin, 127-138.

[8] Rostami, S., Nakhaei, M. and Khodaei, K. (2010) The Effect of Artificial Recharge on Groundwater Potential in Gharve Plain, Kurdistan. The 1st National Conference on Applied Research of Iran Water Resources, Kermanshah.

[9] Parsiopoolos (1995) Vadi Tabalah Aquifer Recharge Evaluation Using Simulation. Saudi Arabia.

[10] Paul, M.J. (2006) Impact of Landuse Pattern on Distributed Groundwater Recharge and Discharge. Chinese Geographical Science. http://dx.doi.org/10.1007/s11769-006-0229-5

[11] Chenini, I. and Ben Mamou, A. (2010) Groundwater Recharge Study in Arid Region. An Approach Using GIS Techniques and Numerical Modeling. Computers and Geosciences, 801-817. http://dx.doi.org/10.1016/j.cageo.2009.06.014

[12] Danaeian, M.R. (1997) Groundwater Evaluation with Emphasis on Natural and Artificial Recharge. Thesis for Requirement of the Degree of Master of Science. International Institute for Aerospace Survey and Earth Science (ITC), Enschede, 190 p.

[13] Ashtiani Moghadam, Gh., Ahmadi, M., Kholghi, M. and Safaeian, N. (2003) Artificial Recharge Model of Naz Plain in Sarry in Order to Prevent the Saltwater Development. Khazar Journal of Agriculture and Natural Resources, 1.

[14] Katibeh, H. and Hafezi, S. (2004) Application of MODFLOW Model and Management by Utilizing Groundwater and Evaluation of the Performance of Artificial Recharge of Ab Barik Plain in Bam. Journal of Water and Wastewater, 50, 45-58.

[15] Rezaei, M. and Sargazi, A. (2009) The Effects of Running Artificial Recharge on the Aquifer of Goharkooh Plain. Journal of Earth Science, 19, 99-106.

[16] Nozarpoor, L. (2014) Water Resources Modeling and Management in Loor Plain, Andimeshk with an Emphasis on the Evaluation of Jarmeh Artificial Recharge. Master's Thesis, Shahid Chamran University, Ahvaz.

[17] Aghanabati, A. (2006) Iran Geology. State Organization of Geology and Mineral Explorations, Tehran, 586 p.

[18] Khuzestan Department of Water and Power (2007) Studies in Recognition of Groundwater in Gotvand-Ahgili Areas. New Earth Analysts Consultant.

[19] Movahedian, A. (2014) Evaluation of Artificial Recharge Using Mathematical Model in Ab Bid-Sarbisheh’s Plain (Northwest of Govand). Master Thesis, Shahid Chamran University, Ahvaz. 